\section{Gebed: 'n Proses wat verandering bemiddel}

D J Human

(Universiteit van Pretoria)

\section{ABSTRACT}

\section{Prayer: A process that mediates change}

Prayer is an integral part of the believer's communion with God. It reflects different dimensions and functions in the faith-relationship between God and man. Worship, praise, thanksgiving, intercession, petition, confession and trust are only a few to be mentioned. A neglected aspected of the prayer experience is the lament. Prayer is, in this sense, an exposure of the self and the circumstances of the petitioner before God. The purpose of this article is to illuminate the theological meaning of the lament as prayer for the individual and the faith community. Prayer is also understood within the broader scope of different expressive human deeds. It is a process which mediates perspective and essential change in the life of the believer and faith community. In a final application it is argued that the lament-prayer can contribute to change and renewal in a transitional and disturbed South African church and society.

\section{INLEIDING}

Die verhouding tussen ' $n$ gelowige en God is nouliks voorstelbaar sonder gebed. Gebed is ' $n$ integrale deel van die Christen-gelowige se lewe. Dit is die ruimte waarbinne die intiemste oomblikke tussen ' $n$ gelowige en God gekoester word. Daarom skep hierdie gemeenskap tussen God en mens vir die gelowige nuwe sin en lewe. Gebed word op hierdie manier die geboorteplek van die gelowige se lewenskrag; dit is die mens se antwoord op God se toenadering in sy lewe. Daarom is gebed vir die gelowige ' $n$ lewenswyse. Daarsonder kwyn die lewe vir hom/haar.

Gebed het egter verskillende dimensies en vorme. In verskillende Bybeltekste bestaan daar verskillende blikpunte en beklemtonings op hierdie gemeenskap-ervaring tussen mens en God. In gebed kom die mens se aanbidding van en verering vir sy Skepper en Redder tot uitdrukking (2 Kron 6:41; Ps 8; Job 19:25). Die lofprysing vir al die genadegawes en die volheid van die lewe wat gelowiges van God ervaar, is ingebou in die opwinding van verskeie lofbetuigings (Pss 145-150; Ef 1:3). Vir die groot dinge wat God in mense se lewens bewerk, word biddend dank en voorbidding aan Hom betuig (Ef 1:15-22; 3:14-20). Tot ' $n$ groot mate word gebede deur gelowiges net tot ' $n$ aantal versoeke gereduseer, maar gelowiges mag met reg ook hulle behoeftes met gebedsversoeke voor God afpleit en smeek (Matt 6:9-14). As uitdrukking van toewyding kan bidders gebed ook as 'n geskenk of gawe na God toe bring (Ps 141:2). Voorts sou hierdie ontmoeting tussen hemel en aarde ' $n$ skuldbelydenis en verootmoediging (2 Sam 12:16; Ps 51) voor die Here kon wees. Al hierdie dimensies van gebed is belangrik en vul mekaar aan in die gebedslewe van gelowiges.

' $n$ Perspektief wat die rykdom van hierdie ontmoeting tussen God en mens verder belig, is dat gebed die ruimte kan wees waarbinne gelowiges hulself, hul situasie en omstandighede voor God kan blootlê. Veral in situasies van hartseer en pyn kan gebed soos ' $n$ kraan wees wat gelowiges oopdraai. Elke noodlydende kan sy/haar omstandighede teenoor God uit-"praat" en uit-"leef" of daaroor mediteer. Gebed is in hierdie opsig vir die gelowige bidder die "ontbloting van jouself". Dit word "n geloofservaring wat gelowiges bewus maak dat hulle hulself aan God gee. Kommunikasie met God word 'n "Selbst-Mitteilung" (Füglister, 1965:48). In hierdie opsig bring gebed perspektiwiese- en/of lewensverandering. Wat die gelowige egter as individu ervaar, kan ook kollektief op die geloofsgemeenskap of kerk in breër verband toegepas word.

Die doel van hierdie artikel is nie om ' $n$ volledige oorsig oor gebed in die Ou- en/of Nuwe Testament te gee nie (vgl Kloppers 1989:1-13; Smit 1997:437-451; O'Kennedy 2000:535-555). Die fokus is eerder om die teologiese betekenis van die Ou Testamentiese klaaglied as gebed vir die individu en gemeenskap te beklemtoon. Die klaaglied as gebed bied die moontlikheid om nuwe (hernude) lewensin te bemiddel deur die bidder se ontbloting voor God. Dit bemiddel perspektiwiese en/of lewensverandering. Om hierdie perspektief van ontbloting voor God nader vanuit die Psalmboek toe te lig, is dit verder nodig om by enkele perspektiewe rondom gebed in die Psalms aan te sluit.

\section{GEBED IN DIE PSALMS}

\subsection{Inleiding}

Die Psalmboek is ' $\mathrm{n}$ gebedsversameling by uitstek (Shenker 1980:37ev; Seybold 1991:71). Dit bevat poëtiese tekste wat uitdrukking gee aan die Israelitiese geloofslewe en lewenservarings (Craigie 1983:26). Alhoewel slegs enkele psalms die aanduiding "gebed" in hul opskrifte bevat (Pss $17 ; 86 ; 90 ; 102 ; 142)$, is die meeste psalms die mens se antwoord of weer-woord aan God, wat Homself aan sy volk bekend gemaak het. Die aktualiteit van die Psalmboek word juis daarin bevestig dat hierdie gebede en gebedsliedere uit ervarings van die alledaagse lewe kom. 
Afgesien van die lewensin wat die gebede in die geloofsleer en lewe(ns) van die eerste bidder(s) gebring het (Füglister 1992:204 ev), wys die Nachwirkungsgeschichte van die Psalter daarop dat die meditasie (Lohfink 1992:200), saamsing of opsê van hierdie gebede gelowiges op 'n ervarings-proses lei. Hierdie ervarings-weg bring vir die eerste maal of by hernuwing herstelde lewensin of geloofsverdieping na vore. Die reëlmatige funksionering van die Psalms binne en buite die Israelitiese kultus asook in die Joodse sinagoge en verskillende Christelike tradisies bevestig dit (Smith 1984:5; Hossfeld \& Zenger 1993:25). Die liturgie is by uitstek ' $n$ baie belangrike ruimte vir die beoefening van die Psalms in al sy verskillende funksies (Old 1995:11 ev).

Vanuit die Psalms kan gebed juis in ' $n$ breë sin verstaan en gedefinieer word. Gebed is nie net ' $n$ aantal versoeke nie, maar sluit ' $n$ verskeidenheid lewenservarings in wat hierdie gemeenskap met God verwoord. Om te bid, beteken dus nie net om sekere dinge van God te vra nie, maar om op verskeie maniere uitdrukking te gee aan jou mens-wees of omstandighede waarin jy jouself binne die kragveld van God se teenwoordigheid bevind (Deist 1978:13-63). Die meelewing van ' $n$ hand op iemand se skouer, 'n traan oor die wang van blydskap, 'n glimlag van vriendskap, ' $\mathrm{n}$ sug van moedeloosheid, ' $\mathrm{n}$ stortvloed van woorde of emosies, soms selfs ' $\mathrm{n}$ woordelose stilte kan alles die inhoud van gebed konstitueer. ' $n$ Gedagte, woord of daad wat op God gerig is, beteken gebed.

\subsection{Verskeie Sitze im Leben}

Die omstandighede waarin mense bid, neem ' $\mathrm{n}$ verskeidenheid van moontlikhede aan. Iemand verloor sy krag en gesondheid (Ps 38); ' $\mathrm{n}$ ander word sosiaal deur sy gemeenskap verstoot - hy word 'n uitgeworpene (Ps 22); ' $\mathrm{n}$ vyand of besettingsmag oorweldig met vernedering, vernietiging, moorde en plundering (Pss 74; 79; 137); nog een se sonde laat hom skuldig voor God sodat hy geen toekoms of uitweg meer sien nie (Ps 32;130). Hierdie situasies staan weer in skerp kontras met ander waarin mense hul verheug en met ' $n$ himne of danklied God se redding en uitkoms besing (Pss 103; 136; 138). Nog ander betuig hul dank (Ps 116); spreek hul vertroue in God uit (Pss 23; 62; 90); maak ' $n$ belofte (Ps 89:35) of doen ' $\mathrm{n}$ belydenis (Pss 118:6-8; 121).

\subsection{Verskillende soorte gebede}

Ten spyte van talle probleme om psalms in kategorieë of genres in te deel, is dit duidelik dat gelowiges hulself soms in verskillende omstandighede kan bevind. Vir hierdie Sitze im Leben sou daar verskillende soorte gebede in die psalms onderskei kon word. Gebede kan ' $n$ volledige psalm uitmaak of dit kan as ' $\mathrm{n}$ bousteen in die psalm funksioneer.
Die volgende beskrywings is ' $\mathrm{n}$ poging enkele kategorieë van psalmgebede daar te stel:

- Versoekende of pleitende gebede: Hierdie gebede kom voor waar gelowiges se siekte, pyn, nood en diepe teleurstelling beskrywe word. Meestal staan hierdie psalms as sogenaamde klaagpsalms of klaagliedere bekend (Pss 3:8; 4:2; 6:3; 7:2; 25:20; 44:24 ens). Dan rig die psalmis sy versoeke, pleitroepe en smeekgebede tot God. Die bidder vra die Here se ingrype in sy situasie. Hy pleit om God se redding in ' $n$ krisis, of die vervulling van ' $n$ lewensbehoefte.

- Himniese of lofprysingsgebede: Himniese gebede is uitsluitlik op die verering van die Here God alleen gerig (Pss $8 ; 29 ; 33 ; 65 ; 113$ ). Lof vir sy grootheid, sy mag asook die skoonheid wat Hy in die skepping tot stand gebring het, word onder woorde gebring. Die onderskeid met die dankgebed is soms moeilik te bepaal. Waar die lofgebede God met ' $n$ liriese toon spesifiek vir sy optrede, sy wese en guns prys, spreek die dankgebede se inhoud God aan vir spesifieke dade aan spesifieke mense. Westermann $(1981: 161,165)$ maak 'n onderskeid tussen berigtende lof (himne) en beskrywende lof (danklied). Eersgenoemde staan in die konteks van die gebeurtenis self, terwyl laasgenoemde in die raam van die kultiese lofprysing funksioneer.

- Dank- en vertrouensgebede: Ongeveer 20 psalms kan in geheel as dankliedere beskou word (bv Pss 30; 32; 34; 40; 118; 138 ens). Wanneer God gebede verhoor en redding uit nood bewerkstellig, bied die volk of ' $n$ enkeling-gelowige hul dankbetuiging teenoor God. Die dank vir die Here se reddingsdade, sy hulp, beskerming en herstel vorm die vernaamste komponent van hierdie gebed. In die dankgebed speel die gelowige se vertroue in God se krag en vermoë ' $n$ belangrike rol (Pss 9:2-10; 27:1-6, 13-14). As deel van die gesprek met God beskryf Ryken et al (1998:659) gebed as "an exchange of confidence" en "posture of trust and confidence".

- Boetedoeningsgebede: ' $n$ Hele aantal gebede sentreer rondom die tema van sondebelydenis (Pss $6 ; 32 ; 38 ; 51 ; 102 ; 130 ; 143$ ). Hierin bely die psalmdigter dat die toorn van die Here oor hom gekom het omdat hy teen God gesondig het. Daarom word boete voor God gedoen oor die sonde wat die bidder gepleeg het. Hierdie boetedoening het tot gevolg dat die psalmis die Here se vergifnis intens ervaar. ' $n$ Nuwe begin in die verhouding met God word daarmee gekonstitueer.

- Bemiddelende gebede: Gebede waarin die bidder iets vir God in belang van iemand anders vra, is bemiddelend van aard. Veral in die sogenaamde koningspsalms (Pss 20; 72; 125:4), waarin die koning ' $n$ prominente rol speel, bid die psalmdigter tot God om hierdie leier by

ISSN 1609-9982 = VERBUM ET ECCLESIA Jrg 22 (1) 2001 
te staan. Hy pleit dat God aan die koning oorwinning, insig om te regeer, ' $n$ sin vir regverdigheid en 'n lang lewe sal gee. Menigmaal word die Here gevra om vir die opregtes van hart goed te wees.

Vanuit hierdie voorbeelde blyk dit dat gebed die kanaal is waardeur die bidder homself in spesifieke situasies voor God kan ontbloot.

\section{3 "OM JOUSELF TE ONTBLOOT"}

Om homself te ontbloot, is nie vir die mens noodwendig ' $n$ aangename ervaring nie. Dit kan ' $n$ pynlike belewenis wees. Die verhaal van Adam en Eva in die tuin van Eden bevestig dit. Na die sondeval en hul ongehoorsaamheid om van die boom van alle kennis te eet, ontdek Adam en Eva skielik hulle eie naaktheid voor God (Gen 3:8-9). Hulle sien hulleself raak in hul skuld: ontbloot in ongehoorsaamheid voor God.

Ontbloting laat die mens weerloos. Dink maar aan die pasiënt wat totaal ontklee moet word om deur die dokter as geobjektiveerde voorwerp ondersoek te word. Dieselfde geld vir die pasiënt wat deur die verpleegkundige in die hospitaal gewas word. Die sfere van intiemste privaatheid word by ontkleding onthul. Iemand anders sien jou soos jy is. Jy kan niks meer wegsteek nie.

Maar tog, as iemand siek of gewond is, maak ontbloting of ontkleding ' $n$ verskil. Wanneer die pyn ondraaglik is en klere aan die wonde vaskleef, wens die pasiënt dat iemand daardie wonde kan skoonmaak. Dan kan die geneesheer of verpleegkundige die klere en komberse maar wegneem. As iemand maar net die wonde kan skoonmaak, word die naak-wees of ontbloting die middel tot ' $n$ doel. Dit is deel van die proses tot herstel.

Ontbloting en ontlading is belangrike handelinge om genesing of nuwe lewe te bespoedig. Die mediese wetenskap en geografie illustreer hierdie proses. Vir ' $n$ sweer om gouer gesond te word, is dit eers nodig om oop te bars of stukkend gesny te word. Eers wanneer die besmettende vloeistowwe gedreineer het, kan die wonde droog word. Dan vorm dit ' $n$ roof wanneer genesing begin intree. ' $n$ Rivier of dam waarin water slegs inloop, word gou met slik en vuilgoed gevul. Dit kan spoedig tot die dood van visse, waterdiere en ander lewende organismes in die water lei. Wanneer daar egter ' $n$ uitloop is en versperrings oopgemaak word, is lewe in die rivier of dam moontlik. Die water daarvan is selfs drinkbaar.

Dieselfde beginsel(s) van ontbloting en ontlading kan toegepas word op die gelowige mens se lewe. Kollektief geld dit ook vir ' $n$ geloofsgemeenskap soos die Kerk. Die Psalms illustreer dit duidelik. Hartstogtelike klagtes en gebede ruk ontredderde bidders (Ps 77) en geloofsgemeenskappe (Pss 74; 79 en 137) se wonde oop. Hierin word juis die angs en frustrasie, die moeite, nood en pyn van gelowige mense hoorbaar. Die Psalmboek is die spreekkamer waarin die mens in nood voor God as Geneesheer van die lewe ontbloot word. Noodlydendes, siekes, onderdruktes en beangstes ontledig hulleself op soek na genesing, beterskap en redding. Met hul klagtes en gebede stel hulle hul vertroue in die Skepper- en Reddergod van Israel en die mensdom.

Om deel te hê aan hierdie katarsis en ontblotingsproses, help dit as gelowiges die Psalms se gebede na-bid. Wanneer gebede gelees, gesing of gebid word, neem gelowiges deel aan hierdie terapeutiese proses wat tot heling en vernuwing lei. In veral nood, hartseer en pyn, maar ook in ander lewensituasies kry die gelowige op hierdie manier deel aan die lydens- en helingsgeskiedenis van die mensheid. Dan help die klaaggebed deurdat gelowiges hul voor God ontbloot. Herstel en genesing kan dan intree, omdat God as die gelowige se Geneesheer, sy oë en hande op die stukkende en naakte lewenswonde werp (Ps 33:13).

\section{DIE RUIMTE WAARBINNE “ONTBLOTING” PLAASVIND}

Om die oënskynlike afwesigheid van God te ervaar, is deel van die gelowige se godservaring (Ps 22; Job $7 ; 16 ; 19$ ). Hierdie ervaring is vir Christene nie vreemd nie. Hulle lewe kwyn soms weg daaronder. Omstandighede word verder verswaar deur die meegaande hartseer en pyn asook skuld en nood wat hulle oorval. Noodlydende gelowiges neig dan soms om God en medemens te vermy. So forseer eensaamheid en verstotenheid mense verder in die put van depressie en donkerte. Maar die sweer van neerdrukkende omstandighede kan egter oopgesny word. Wie genesing verlang, kan sorg dat lewenswonde oopgemaak word.

' $n$ Mens ontbloot hom/haarself egter nie voor enigiemand of op enige plek nie. Daarom is die teenwoordige oor van God die aangewese ruimte waar gelowiges hulself en hul omstandighede van skuld of krisis kan ontledig (Ps 62:2, 6-9). Om hierdie rede wend psalmbidders hulle uitsluitlik in gebed tot die Here, hulle God. Deur gebed kan gelowiges hulle in hul omstandighede voor God ontklee. Dit is dan wanneer hulle die ruimte van God se liefde betree. Binne hierdie ruimte kan die kwelling, angs en vrees verdryf word (1 Joh $4: 18$ ), sodat genesing en nuwe lewe intree. Daarom ontbloot die bidder sy lewe en omstandighede deur gebed in die teenwoordigheid van God.

\section{DIE KLAAGLIED - "N VORM VAN "ONTBLOTING"}

\subsection{Inleiding}

Die taal en vorm van die Ou-Testamentiese klaaglied bied aan gelowiges die kanaal om hulself in hul nood voor God te ontbloot (Miller 1994:69 ev). Aan die hand van Psalm 22 het Fuchs (1982:354) reeds die belang en gebruik van die klag/klaaglied as gebed in die geloofslewe bepleit. In 
sowel die Ou- as Nuwe Testament is die klag 'n natuurlike element van die gelowige se lewe. In die Ou Testament vorm dit " $n$ integrale deel van die gebedsinhoud. Dit is ' $n$ onvervangbare komponent van aanbidding. Soos lofprysing die taal van vreugde is, so gee die klaaglied uitdrukking aan die taal van krisis en lyding.

Meer as ' $n$ derde van die psalms is sogenaamde klaagpsalms. Sowel die enkeling-gelowige as die volk Israel druk hulle pyn en benoudheid voor God uit. Daarom bestaan daar in die Psalmboek klaagliedere van die volk (bv Pss $44 ; 60 ; 74 ; 79 ; 80 ; 83 ; 89 ; 90 ; 137$ ) én klaagliedere van die individu (bv Pss $3 ; 5-7 ; 13 ; 17 ; 22 ; 25-28 ; 35 ; 38-9 ; 41-43 ; 51$; 54$57 ; 59 ; 61 ; 63-64 ; 69 ; 71 ; 86 ; 88 ; 102 ; 109 ; 130 ; 140 ; 141 ; 143)$. Reeds van die vroegste tye af verwoord die klaaglied gelowiges se hoopvolle verwagting op en saamleef met God. Hiervan spreek die voorbeelde van Kain (Gen 4:13), Abraham (Gen 15:2), Rebekka (Gen 25:22; 27:46), Ismael (Gen 21:16ev), Simson (Rig 15:18), Hanna (1 Sam 1:10-12), Hiskia (Jes 38), Job en Habakuk duidelik.

\subsection{Klaaglied - ondankbaarheid teenoor die genadige God?}

Om met die woorde van ' $n$ klaaglied jouself voor God te ontledig, is allermins ' $n$ aanduiding van ondankbaarheid teenoor die Here. Christene interpreteer die Ou-Testamentiese klaaglied menigmaal in hierdie lig. Maar hierdie vorm van gebed spreek eerder van ' $n$ beweging na God toe. In die uitdrukking van die nood en wanhoop word juis aan God vasgehou. Erkenning word daaraan verleen dat $\mathrm{Hy}$ in staat is om redding en $\mathrm{krag}$ in die gelowige se lewe te bewerkstellig. Iemand ontbloot sigself juis voor God in vertroue dat die Een teenoor wie gekla word, die mag het om te help. Om ' $n$ klaaglied oor die lippe te neem, beteken dat:

- die bidder die uitsigloosheid van die noodsituasie beklemtoon;

- die gelowige se onvermoë om te red, voor God bely word;

- die bidder se afhanklikheid van God besef word

- die gelowige die reddingskrag van God veronderstel.

In beginsel dui die gebruik van die klaaglied op die teenoorgestelde van 'n ondankbare reaksie teenoor God. Inteendeel, die mag van God word juis daarmee erken, terwyl die bidder se eie swakheid en onvermoë die krag van God beklemtoon.

\subsection{Klaaglied - een muntstuk met twee kante}

Die begrip "klaaglied" bestaan uit twee komponente. Dit bevat die momente van klag en lied. Beide is steunpilare waarop die brug tussen hemel en aarde gebou word. Die klag veronderstel die ontbloting van die bidder voor God, terwyl die lied die uitroepteken in hierdie gemeenskapservaring verwoord. In die lied word lof en vreugde oor verlossing en bevryding van die noodlydende hoorbaar. Klag en lof is dus twee kante van dieselfde muntstuk. Die een roep die ander een op; die een sluit die ander een nie uit nie. Wanneer iemand klaagroepe voor God uitspel, word bewondering en vertroue op God se hulp antisipeer, anders sou die bidder waarskynlik nie gekla het nie.

\subsection{Verskillende elemente van die klaaglied}

Die Ou-Testamentiese klaaglied bevat ' $n$ hele aantal elemente (Wevers, 1956:80ev; Gerstenberger, 1988:12 en talle ander). Hierdie lied druk eintlik ' $n$ proses uit in die lewe van gelowiges, wat in die greep van lyding en wanhoop beland het. Hierdie klaaglied-proses is ' $n$ ervaring wat in die konkrete lewe oor ' $n$ tydperk heen kan verloop. Vanuit die Psalmboek blyk die verskillende elemente van hierdie gebedsproses soos volg:

- Aanroep van God se Naam (Pss 13:1; 25:1; 28:1; 31:2-5; 54:3-5; $83: 2 ; 88: 2-3 ; 102: 2-30)$. Die bidder gebruik uitdrukkings soos "Red my deur u mag, o God", "Ek roep na U, Here, my Rots (Ps 28:1)", "Tot U, Here, rig ek my (Ps 25:1)". Hierdie aanroep van God se naam verskerp die dringendheid en erns waarmee die bidder sy/haar saak voor God stel. Dit beklemtoon ook die intensiteit van elkeen se pyn en hartseer.

- Klaaguitdrukkings (Pss 22.2-3; 7-9; 13-19; 35:7; 11-16; 38:3-15; 102:4-12; 143:3-6). Die bidders maak hul hart oop voor God oor die noodlydende omstandighede waarin hulle hul bevind: "Waarom hou u aan om ons te verstoot" (Ps 74:1), "Ek het alle moed verloor, ek is verslae" (Ps 143:4), "Ek voel so verlate soos "n pelikaan in 'n woestyn" (Ps 102:7). Daarmee ontbloot elke noodlydende of gemeenskap die vraagtekens wat deur die smart in hul lewens veroorsaak is. Met die uitsondering van Psalm 88 is dit opvallend dat geen Ou-Testamentiese klaaglied met ' $\mathrm{n}$ klag of klaaguitdrukking eindig nie.

- Rede(s) waarom God moet ingryp (Pss 13:5 25:11; 143:11). Sommige bidders motiveer in gebede waarom God in hulle lewe moet ingryp. Hulle gee redes soos "anders sê my vyand hy het my oorwin" (Ps 13:5), "Ter wille van u Naam Here, vergewe my my sonde" (Ps 25:11) of "Ter wille van u Naam Here, laat my lewe" (Ps 143:11). Gelowiges kan en mag God nie in hul gebede manipuleer nie. Daarvoor is God te soewerein (Jona 3:9-10). Hierdie redes waarom God moet ingryp, verklaar ook nie Sy onkunde oor of onbetrokkenheid by die lewe van die bidder nie. Vir die bidder is hierdie redes deel van ' $n$ 
katarsis-ervaring. Bidders verwoord hulle verwagting van God en spel eerlik uit waarom Hy op hul biddende verwagting moet reageer.

- Belydenis van sonde of onskuld (Pss 7:4-6; 26:4-6; 32:3-7; 38:19; 44:19-20; 51:5-7; 130:2-4). Gelowiges gaan soms swaar gebuk onder hul eie sonde of beskuldigings van ander mense. Om dit voor God te bely, bring weer nuwe lewe en uitsigte (Ps 32:6). Daarom kan bidders onder andere voor God sê: "Ek bely my ongeregtigheid, my sonde kwel my". Dit bring verligting en sluit die lewe vir die bidder weer oop (Ps 130:2-4). Hierteenoor beleef ander hulle lewenslot soms as onregverdig. Veral by siekte is daar by die psalmdigter ' $\mathrm{n}$ protes om sy/haar onskuld te beklemtoon (Wevers, 1956:90). Die verklaring van onskuld kan ook die godsvolk se ervaring wees. So sê Israel byvoorbeeld: "Al hierdie dinge het oor ons gekom alhoewel ons u nie vergeet het nie, en aan u verbond nie ontrou was nie" (Ps 44:19).

-Vertrouensuitsprake (Pss 22:5-6; 25:2,21; 31:7-9; 56:4-5; 71:5-7). In sogenaamde klaagliedere spreek bidders dikwels hul vertroue in en teenoor God uit. Bloot die feit dat gelowiges God in verskillende omstandighede nader, spreek as ' $n$ daad van vertroue in Hom. Vertroue word ook eksplisiet verwoord in bedes soos "want u Here, is my hoop, op u het ek van jongs af vertrou" (Ps 71:5), "Die dag as ek bang word, vertrou ek net op U" (Ps 56:4).

- Gebedsversoeke, pleit- en hulproepe (Pss 7:7-10; 17:6-9; 35:1-3, 22$24 ; 51: 9-14 ; 69: 14-19 ; 143: 7-11)$. Sowel individue as die geloofsgemeenskap vra dat God in hulle nood en lewensbehoeftes sal voorsien. Daarom pleit hulle by Hom as deel van hulle soeke na uitkoms uit huidige omstandighede: "Moet tog nie u dienaar alleen laat nie! Ek is in groot gevaar, antwoord my tog gou!" (Ps 69:18), "Beskerm my soos die appel van u oog" (Ps 17:8), "gee my tog nuwe lewenskrag" (Ps 13:4), "Kom my te hulp" (Ps 7:7).

- Erkenning van God se optrede (Pss 6:9-11; 22:22; 56:10; 140:13). Psalmdigters erken God se reaksie op hulle (vroeëre) pleitredes en versoeke. Dit spreek uit frases soos "want die Here het ag geslaan op my geroep om hulp, die Here het geluister na my smeking" (Ps 6:910), "U het my gebed verhoor" (Ps 22:22), "Ek weet, die Here behartig die regsaak van die hulpelose. Hy sorg vir die reg van die arme" (Ps 140:13). Hierdie erkennings getuig van vertroue in God en bevestig dat gebed vir gelowiges ' $n$ belangrike proses tot die ervaring van nuwe uitsigte en lewensomstandighede is.

- Gelofte/Belydenis (Pss 7:18; 22:26; 56:13; 109:30). Hierdie elemente is eng verweef aan die verklaring van vertroue en lof. As toesegging van voortgesette of hernude toewyding aan God binne die huidige lewensomstandighede, maak psalmdigters hul eie gesindheid teenoor God bekend. Uitdrukkings soos "Ek moet my geloftes aan u nakom, o
God, ek wil U met dankoffers betaal" (Ps 56:13), "my geloftes sal ek nakom voor die mense wat Hom dien" (Ps 22:26) bevestig dat die Ou-Testamentiese klaaglied nie ' $n$ daad van ondankbaarheid teenoor God uitdruk nie. Dit word begelei deur die bidder se gesindheid van lof en vertroue.

- Verwagtingsvolle danksegging (Pss 22:23-27; 31:20-25; 69:31-37). In talle klaagliedere blyk dit asof die bidder God dank nog voordat Hy werklike uitkoms uit noodomstandighede gee. Dit bevestig die bidder se vertroue in Hom. Die digter in Psalm 69 bid byvoorbeeld: "Ek is ' $n$ hulpelose mens, vol pyn, maar $U$, o God, sal my red en my beskerm. Dan sal ek die Naam van die Here besing, Hom met ' $\mathrm{n}$ danklied prys..." (Ps 69:30 ev).

- Himniese- en lofuitdrukkings (Pss 13:6; 22:4; 25:8-10; 59:6; 83:19). Feitlik alle klaagliedere in die Ou Testament bevat himniese elemente of lofbetuigings. Psalm 88 is in hierdie opsig die enigste uitsondering. Uitsprake soos "U (is) die Allerhoogste oor die hele aarde" (Ps 83:19), "oor die uitkoms wat u gee, juig my hart" (Ps 13:6) of "God is van altyd af my koning, dit is Hy wat op die aarde redding bring" (Ps $74: 12$ ) illustreer die lof. Dit vorm 'n hoogtepunt in bidders se geloofservaring asook in hul verhouding met God. Vreugde en lof gee op hierdie manier uitdrukking aan die gelowige bidder se singewende verhouding met God. Gebed blyk ' $n$ belangrike kanaal of proses waardeur hierdie singewing verwoord en ervaar word.

Nie alle sogenaamde klaagliedere in die Psalmboek of in die Ou Testament bevat al die bogenoemde elemente nie. ' $n$ Klaaglied bevat soms net enkele van die bogenoemde boustene. Die belangrikste elemente wat meestal voorkom, kan an die hand van Psalm 13 illustreer word. Elemente in hierdie psalm is die aanroep God se naam (13:2), klag (13:2-3), gebedsversoeke (13:4-5), vertrouensuitsprake (13:6) en lofbetuigings (13:6-7). Psalm 13 is in hierdie opsig 'n eksemplariese model van die klaaglied-gebed (Prinsloo, 2000:47). Deur die hele klaagproses heen beweeg die bidder dus van klag tot vertroue tot lof en dank; van uitsigloosheid tot die aanbreek van ' $n$ nuwe lewensbegin.

\section{GEVOLGE VAN HIERDIE “ONTBLOTING”}

Deur die taal van die klaaglied op die lippe te neem, word gebed vir die gelowige ' $n$ ontblotingsproses. Om voor God, die Lewensgeneesheer, oor angs en lyding, skuld en wanhoop te praat, bring verligting. Sy teenwoordigheid inspireer die bidder om uit te praat en sy/haar diepste binneste ten toon te stel. So ' $n$ ontboeseming bring reiniging (Ps 51). Dit verander die bedreigende doods-ervaringe weer in ' $n$ nuwe lewe. Die gevolge hiervan sluit onder andere die volgende aspekte in:

ISSN 1609-9982 = VERBUM ET ECCLESIA Jrg 22 (1) 2001 
- 'n Nuwe begin: Wanneer iemand ' $n$ klaaggebed bid, en uiteindelik deur die klagproses heen tot by die vertroue, dank- en lofelemente kom, beteken dit dat die bidder ' $n$ ander (nuwe?) uitsig op sy/haar krisisomstandighede ontwikkel het. Dit impliseer dat die gelowige bidder ' $n$ vryheid ervaar te midde van die doodsnood. ' $n$ Nuwe begin word met die lewe gemak. Daarmee ontkiem nuwe lewensmoontlikhede vanuit die doodsomstandighede.

- Nuwe perspektief: Wanneer gelowiges God se krag in hul lewens raaksien en ervaar, bring dit nuwe perspektief op God, hulself en hul noodsituasie. Die gerigtheid op God met vertroue, dank, belydenis en lof verander die perspektief op lewensomstandighede. Dit skep hoop in die gelowige se lewe. Habakuk sê: "Al sou die vyeboom nie bot nie... nogtans sal ek in die Here jubel!" (Hab 3:17 ev). Al sou die bedreigende omstandighede letterlik nie opgehef word nie, kry die noodlydendes ' $n$ nuwe perspektief op God, hulself en die lewe.

- Nuwe toewyding: Noodlydendes, wat met nuwe perspektiewe uit doodsomstandighede opstaan en met nuwe oë na hulself en hul krisisomstandighede kyk, kan met nuwe ywer en toewyding in afhanklikheid van God voortlewe. Elkeen wat God se redding ervaar, word met nuwe krag en entoesiasme begeester. Talle lofbeloftes en geloftes wat psalmdigters in hul klaaggebede maak (Pss 22:23-27; 31:20-25; 69:31-37), bevestig dat hul klag-ontblotings voor God tot ' $n$ verinniging van hul verhouding met die Here lei. Gelowiges kan dus hierdie herwinde lewenskrag opnuut met woord en daad op God rig.

- Nuwe vastrapplek: Mense wat vanweë krisisse in (gebeds)worsteling met God verkeer het, kom tot die oortuiging dat Hy wat red, die gelowige met nuwe hanteringsmeganismes toerus. Ná Habakuk se worsteling met God en die bedreigende nood kom hy tot die gevolgtrekking: "Die Here my God gee vir my krag. Hy maak my voete soos dié van "n ribbok. Op hoë plekke laat Hy my veilig loop" (Hab 3:19). Ten spyte van bedreigende lewensgevare gee God vir die worstelende gelowige die krag en vlugvoetigheid om nie die los klippe op die hoë kranse van die lewe raak te trap nie. Gelowiges kan met God se krag oor die gevaarlike afgronde van die lewe beweeg. Dit bevestig dat die gelowige bidder ' $n$ nuwe greep op sy/haar lewe en noodomstandighede kan kry.

- Nuwe rustigheid: Uit die worstelende ontbloting voor God kom die noodlydendes tot die insig dat hul lewe by God tot rus kom. Herstel en genesing lê dus by God. Rustigheid in die ontstuimige lewe van die worstelaar is die direkte gevolg van God se goedheid (Ps 116:7). Hy is die Een wat uitkoms en redding bewerk. Nie die ontblotingsproses of die gebed is die oorsaak van die heling nie, maar God self. Rus en veiligheid ná die katarsis van 'n klaaggebed is gesetel by God self.
Uit die belydenis van die psalmdigter is dit duidelik: "Net by God vind ek rus" (Ps 62:2, 6).

\section{TOEPASSING: GEBED EN VERANDERING IN KERK EN SAMELEWING}

Gebed speel ' $n$ belangrike rol in die verhouding tussen God en gelowiges. In verskillende omstandighede kan gebed verskillende vorme aanneem. Funksies van gebed in verskillende Sitze im Leben verskil eweneens. Verskeie soorte gebede in byvoorbeeld die Psalmboek onderstreep hierdie onderskeide.

' $n$ Perspektief wat die rykdom van hierdie ontmoeting tussen God en mens verder belig, is dat gebed die ruimte kan wees waarbinne gelowiges hulself, hul situasie en omstandighede voor God kan blootlê. Dit gebeur in die Ou-Testamentiese klaaglied. Die teologiese betekenis van die klaaglied as gebed bied die moontlikheid om nuwe (hernude) lewensin in gelowiges se lewe te bemiddel. Deur die bidder se ontbloting voor God bemiddel die gebedsproses perspektiwiese en/of lewensverandering. Vir sowel die individu as vir die breër geloofsgemeenskap soos die Kerk kan gebed dus verandering en vernuwing bemiddel. Verandering beteken onder andere ' $n$ nuwe begin, nuwe perspektief, nuwe vastrapplek, nuwe toewyding en nuwe rustigheid.

Vir die huidige Suid-Afrikaanse gemeenskap kan hierdie perspektiewe betekenisvol wees. Kerk en samelewing gaan aan die begin van ' $n$ politieke oorgangsperiode en ' $n$ nuwe millennium gebuk onder vele veranderings. Onsekerheid in hierdie tyd word begelei deur die buitengewone voorkoms van gewapende roof en diefstal, huisinbrake, moored, korrupsie binne en buite Staatsdepartemente, asook toenemende geweld op alle terreine. Oneerlikheid is in die samelewing aan die orde van die dag. Teleurstelling in sosiale, politieke en godsdiensleiers neem toe. Mense word gevangenes in hulle eie gepanserde huise en omheinde woonbuurtes. Ander verhuis na beter weivelde waar die waarde van die Rand en die veiligheid van woon- en werkplek beter is. Die kloof tussen armes en rykes, eerste- en derdewêreld omstandighede word groter.

Waarmee kan die Kerk in hierdie omstandighede antwoord? Baie mense het reeds gevlug in onnadenkende vorme van godsdiens. Ander verketter mekaar vir liberale teologiese standpunte en gaan voort om tradisionele standpunte onkrities te vertroetel. 'n Oorvloed van oppervlakkige godsdienstige literatuur verseker dat godsdiens die opium van die kerkvolk bly. Eredienste word charismatiese "shows", terwyl prediking vervlak vanweë die feit dat predikante en pastors aanmekaar ausserirdische-Amerikaanse kerkmodelle cito-cito op Suid-Afrikaanse bodem afdruk. ' $n$ Gebrek aan grondige Bybeluitleg en kennis laat prediking vervlak tot moralistiese troosboodskappies. 
Is die antwoord op hierdie situasie dan gebed? Of die klaaglied? Nie op die manier waar gebed as ' $n$-handegevoude-ö̈-geslote-pleitversoekende klompie woorde tot God verstaan word nie. 'n Gebedsvroomheid sonder konkrete dade is nie die bedoeling waarop hierdie argumentering afstuur nie. Gebed in die breë sin as ' $n$ praktiese lewenswyse wat aspekte van die klaaglied konkretiseer kan perspektiwiese en lewensverandering in Kerk en samelewing bewerkstellig. Dit geld vir die individu en vir geloofsgemeenskappe.

Die individuele gelowige moet veel meer worstelend en krities met God in sy persoonlike omstandighede omgaan. Christene beskou die klaaglied-proses te veel as ' $n$ ondankbare daad teenoor God. Daarmee ontken hulle in effek hul pyn en noodlydende omstandighede. Hulle voel skuldig as hulle God met vraagtekens konfronteer. Om deur die klaaglied se ontblotingsproses heen by versoeke, vertroue, dank, belydenis en lof teenoor God uit te kom, kan vir die gelowige ook perspektiwiese en lewensverandering tot gevolg hê. Maar dan moet gebed as konkrete lewenshandelinge verstaan word. Vertroue, dank, belydenis en lof moet ná die klag as konkrete dade teenoor God en medemense tot uitdrukking kom. In hierdie sin word gebed "an avenue of service" (Ryken et al, 1998:660). Die belangrikste doelstelling van gebed moet wees om krag te skep wat ander help. Om in lydensomstandighede eerlik en ernstig met God te worstel, is dus belangrik. Dit kan die moontlikhede tot ' $\mathrm{n}$ nuwe begin, nuwe perspektiewe op God, jouself en jou noodomstandighede, nuwe toewyding aan God, Kerk en samelewing, asook ' $\mathrm{n}$ nuwe vastrapplek en rus tot gevolg hê. Daarmee kry die lewe nuwe kleur en sin

Wat op mikro-vlak met die individuele gelowige gebeur, kan op makro-vlak deur die Kerk of geloofsgemeenskap implimenteer word. In sowel die liturgie as in die sosiale betrokkenheid van die Kerk binne die samelewing kan die klaaglied as gebed ' $\mathrm{n}$ rol speel om verandering te bemiddel. Die Kerk se kritiese betrokkenheid by die politiek en ander sosiale strukture kan lidmate tot konkrete dade van vertroue, dank, belydenis en lof teenoor God anmoedig. Dit kan die lewe en perspektiewe op lydensomstandighede van Kerk en individu in " $n$ ander lig stel. Natuurlik kan hierdie ontblotingsproses voor God begelei word met die opregte gebedsversoeke van gelowiges in woord en gedagte.

\section{Literatuurverwysings}

Craigie, P C 1983. Psalms 1-50 (WBC 19). Waco/Texas: Word

Deist, F E 1978. Tussen angs en sekerheid. Gedagtes rondom gebed. Kaapstad Tafelberg.

Fuchs, O 1982. Die Klage als Gebet. Eine theologische Besinnung am Beispiel des Psalms 22. München: Kösel.

Füglister, N 1965. Das Psalmengebet. München: Kösel Verlag.
-, 1992. Die Verwendung des Psalters zur Zeit Jesu. Der Psalter als Lehr- und Lesebuch. Bibel und Kirche, 47/4, 201-208.

Gerstenberger, E S 1988. Psalms, Part 1. With an introduction to cultic poetry (FOTL Series 14). Grand Rapids/Michigan: Eerdmans.

Hossfeld, F L \& Zenger E 1993. Die Psalmen: Psalm 1-50 (NEB). Würzburg: Echter Verlag.

Jung, K N 1984. Prayer in the Psalms. in: Carson, D A (Ed), Teach us to Pray. Cape Town: Oxford University Press, 35-57.

Keel, O 1972. Die Welt der altorientalischer Bildsymbolik und das Alte Testament. Am Beispiel der Psalmen. Zürich: Benzinger Verlag.

Kloppers, M H O 1989. Gebed in die Ou Testament. Acta Theologica, 9, 1-13.

Lohfink, N 1992. Der Psalter und die christlihce Meditation. Die Bedeutung de Endredaktion für das Verständnis des Psalters. Bibel und Kirche, 47/4, 195 200.

Miller, P D 1994. They cried to the Lord. The form and theology of Biblical prayer. Minneapolis: Fortress.

O'Kennedy, D F 2000. Gebed in die Ou en Nuwe Testament. 'n Vergelykende studie. In die Skriflig, 34/4, 535-555.

Old, H O 1995. Leading in prayer. A workbook for worship. Grand Rapids/Michigan: Eerdmans.

Prinsloo, W S 2000. Die lof van my God solank ek lewe. Irene: Medpharm Publikasie.

Ryken, L, Wilhoit, J C \& Longman III, T 1998. Dictionary of Biblical Imagery. Leicester: InterVarsity Press.

Schenker, A 1980. Das Gebet im Lichte der Psalmen. Bibel und Kirche 1/1, 37-41.

Seybold, K 1991. Die Psalmen. Eine Einführung. Köln: Kohlhammer.

Smith, R L 1984. The use and influence of the Psalms. Southwestern Journal of Theology 27/1, 5-17.

Smit, E J 1997. Die voorkoms en betekenis van gebede in die Ou Testament. In die Skriflig, 31/4, 437-451.

Westermann, C 1974. The Role of the Lament in the Theology of the Old Testament Interpretation 28, 20-39.

1981. Hooflijnen van een theologie van het Oude Testament. Kampen: Kok.

Wevers, J W 1956. A Study in the form Criticism of Individual Complaint Psalms. Vetus Testamentum 6, 80-96. 